\title{
芳炔参与二氧化碳化学转化的研究进展
}

刘岗, 马然*

陕西科技大学化学与化工学院, 陕西省轻化工助剂重点实验室, 西安 710021

*联系人, E-mail: maran@sust.edu.cn

2020-04-01 收稿, 2020-05-23 修回, 2020-06-22 接受, 2020-07-13 网络版发表

陕西省自然科学基础研究计划(2019JQ-037)和中国博士后科学基金(2019M650253)资助

摘要 作为可再生的碳一资源, 二氧化碳的化学转化具有重要的生态意义和经济价值. 苯炔是高活性的中间体, 其 参与的二氧化碳的化学转化反应可以实现苯环邻位同时构建两个官能团的策略, 在温和条件下有效构筑 $\mathrm{C}_{\text {芳基 }}$ $\mathrm{C}_{\mathrm{CO}_{2}}$ 键, 得到精细化学品中重要的中间体芳香羧酸类化合物. 本文总结了苯炔经由亲核试剂驱动参与的二氧化碳 的多组分反应, 以及过渡金属催化的反应, 并着重描述其反应特性和反应机理.

关键词苯炔, 亲核试剂, 二氧化碳转化, 多组分反应, 芳香羧酸衍生物

工业的快速发展使得大气中 $\mathrm{CO}_{2}$ 的浓度逐年上升, 美国国家海洋和大气管理局监测的数据显示, 2019年5 月全球二氧化碳浓度再创新高 (414.7 ppm, parts per million). $\mathrm{CO}_{2}$ 是温室气体的主要成分, 日益增加的 $\mathrm{CO}_{2}$ 含量可能会引起全球气候变暖这一不可逆转的灾难. 另一方面, $\mathrm{CO}_{2}$ 也是地球上储量丰富、分布广泛的碳一 资源，具有廉价易得、不可燃、无毒且可再生等优点. 从环境保护和资源利用的角度出发, $\mathrm{CO}_{2}$ 的化学转化具 有重要的生态意义和经济价值 ${ }^{[1,2]}$. 从结构上来说, $\mathrm{CO}_{2}$ 分子中碳原子处于最高氧化价态 $(+4$ 价), 为非极性分 子, 但是含有两个极性的 $\mathrm{C}=\mathrm{O}$ 键, 其中碳原子具有一定 的亲电性, 而氧原子具有亲核性. 也就是说, 二氧化碳 分子即可以作为弱亲核试剂, 也可以作为弱亲电试剂, 通过选择高活性的催化剂(如过渡金属、氮杂环卡 宾、胺类等)或者高能量的起始原料(如不饱和烃类、 环氧丙烷、氮杂环丙烷、金属有机试剂等)可以实现 $\mathrm{CO}_{2}$ 的化学转化 ${ }^{[3]}$. 在此基础上, 以 $\mathrm{CO}_{2}$ 为碳一合成子通 过构筑 $\mathrm{C}-\mathrm{C} 、 \mathrm{C}-\mathrm{N} 、 \mathrm{C}-\mathrm{O} 、 \mathrm{C}-\mathrm{H}$ 键, 可以合成碳酸 酯、噁唑啉酮、喹唑啉二酮、脲类衍生物、氨基甲酸 酯、异氭酸酯、聚胺酯、甲酸、甲醇、羧酸类衍生物
等 ${ }^{[4-8]}$. 目前工业上利用的二氧化碳主要是用于制备尿 素、环状碳酸酯、链状碳酸酯、水杨酸、甲醇等, 产 品结构单一. 如何实现将 $\mathrm{CO}_{2}$ 最大化地为人类生产生活 服务已经引起了科学和工业界的广泛关注.

在众多转化 $\mathrm{CO}_{2}$ 的化学途径中, 由 $\mathrm{CO}_{2}$ 直接生成羧 酸的 $\mathrm{C}-\mathrm{C}$ 键形成反应被广泛研究和深人探索 ${ }^{[9 \sim 11]}$. 这是 因为羧酸类化合物, 尤其是芳香羧酸类化合物, 是精细 化学品生产中普遍使用的中间体, 广泛存在于各类药 物结构中. Grignard试剂、有机锌试剂 ${ }^{[12]}$ 、有机硼试 剂 ${ }^{[13]}$ 、有机锡试剂 ${ }^{[14]}$ 等都可以与 $\mathrm{CO}_{2}$ 发生反应得到相 应的羧酸化合物. 近年来, 芳炔参与的 $\mathrm{CO}_{2}$ 的化学转化 反应逐渐引起化学工作者的关注，主要是以亲核试剂 为驱动进行的多组分反应. 这是因为在芳炔分子中, 存 在一个不同于普通炔烃的碳碳三键 $($ 一个 $\pi$ 键是由芳环 相邻碳原子上未参与成键的 $\mathrm{p}$ 轨道肩并肩重叠形成, 该 $\pi$ 键仍存在于芳环的大 $\pi$ 体系中; 另一个则是由芳环上 相邻碳原子上的 $\mathrm{sp}^{2}$ 轨道侧面部分重叠形成, 且垂直于 苯环的大 $\pi$ 键), 使得芳炔具有能量较低的LUMO轨道 和能量较高的HOMO轨道, 易于接受亲核试剂的进攻. 产生的芳基负离子被 $\mathrm{CO}_{2}$ 捕获, 在温和条件下有效构筑

引用格式: 刘岗, 马然. 芳炔参与二氧化碳化学转化的研究进展. 科学通报, 2021, 66: 739-747

Liu L, Ma R. Recent progress in $\mathrm{CO}_{2}$ transformation with arynes (in Chinese). Chin Sci Bull, 2021, 66: 739-747, doi: 10.1360/TB-2020-0353 
$\mathrm{C}_{\text {芳基 }}-\mathrm{C}_{\mathrm{CO}_{2}}$ 键，而产生的羧酸盐负离子还可以发生分子 内的关环反应, 得到杂环类化合物, 如异香豆素、苯并 噁嗪酮、邻苯二甲酰亚胺等. 目前已报道的苯炔与 $\mathrm{CO}_{2}$ 的多组分反应都是基于Kobayashi类(邻(三甲基硅基)苯 基三氟甲磺酸)苯炔前体 ${ }^{[15]}$. 本文将按照反应机理和亲 核试剂类型对苯炔参与的 $\mathrm{CO}_{2}$ 化学转化反应进行总结, 希望能够对后续研究者有所借鉴.

\section{1 以亲核加成为驱动的多组分反应}

苯炔 $\mathrm{C} \equiv \mathrm{C}$ 键结构的特殊性使其易于接受亲核试剂 的进攻, 形成的苯基碳负离子被亲电性的 $\mathrm{CO}_{2}$ 捕捉, 这 就使得苯炔参与的 $\mathrm{CO}_{2}$ 化学转化反应大多都是多组分 反应. 这里按照亲核试剂的类型对其进行分类(图1).

\section{1 氮亲核试剂}

2006年, 日本广岛大学Yoshida课题组 ${ }^{[16]}$ 首次报道 了苯炔参与的 $\mathrm{CO}_{2}$ 化学转化反应, 发展了亚胺、苯 炔、 $\mathrm{CO}_{2}$ 的三组分偶联反应, 以较高收率在常压下得 到具有药理活性的苯并啞嗪酮类衍生物. 研究者巧妙 地利用了亚胺分子中具有亲核性的氮原子和具有亲 电性的 $\mathrm{C}=\mathrm{N}$ 键: 首先, 氮原子亲核进攻苯炔产生活性的 两性离子中间体 $1, \mathrm{CO}_{2}$ 作为亲电试剂被苯基碳负离子 捕获，得到羧酸负离子中间体 2 ; 随后，亚胺结构中亲 电性的 $\mathrm{C}=\mathrm{N}$ 键接受羧酸盐氧负离子的进攻, 使电荷中 性化, 即得到期望的环化产物. 反应的区域选择性则
与不对称芳炔前体的电子和位阻效应有关，如氟原子 的诱导吸电子效应使得亲核试剂进攻氟原子对位时 得到的苯基碳负离子中间体更加稳定(图2(a)). 而甲氧 基的给电子诱导效应使得邻位的碳原子负电荷更加 集中，不利于亲核试剂的进攻(图2(b)). 甲基的给电子 能力较弱, 对反应选择性的影响主要是受位阻效应控 制(图2(c)).

胺类化合物的 $\mathrm{N}$-芳基化是有机合成中研究的热点, 这是因为其对应的芳基化产物往往存在于具有生物活 性的天然产物、农药、HIV蛋白酶抑制剂等 ${ }^{[17]}$. 2008 年, Yoshida课题组 ${ }^{[18]}$ 延续之前的策略, 发展了仲胺、 苯炔、 $\mathrm{CO}_{2}$ 的三组分反应, 在常压下实现了邻氨基苯甲 酸的合成(图3). 该反应之所以能顺利进行, 得益于中间 体3中氨基氢原子与 $\mathrm{CO}_{2}$ 氧原子之间的氢键: 氢键使得 碳原子的电正性增强，有利于苯基负离子的亲核进攻, 从而避免了胺芳基化副产物的生成 ${ }^{[19]}$. 反应的普适性 研究表明链状脂肪仲胺的反应活性要优于环状的脂肪 仲胺.

使用三级芳香胺代替脂肪仲胺进行苯炔、 $\mathrm{CO}_{2}$ 的 多组分反应时，反应过程涉及氮原子上基团的迁移过 程(图4) ${ }^{[20]}$. 芳香胺上取代基的电子效应对产物结构有 很大的影响: 当芳环上连有给电子基团或者电中性的 基团时, 烷基优先迁移, 得到2-芳氨基苯甲酸酯衍生物 5; 当芳环上连有吸电子基团时, 则芳环优先迁移, 得到 2-氨基苯甲酸芳酯的产物 7. 控制实验表明烷基的迁移
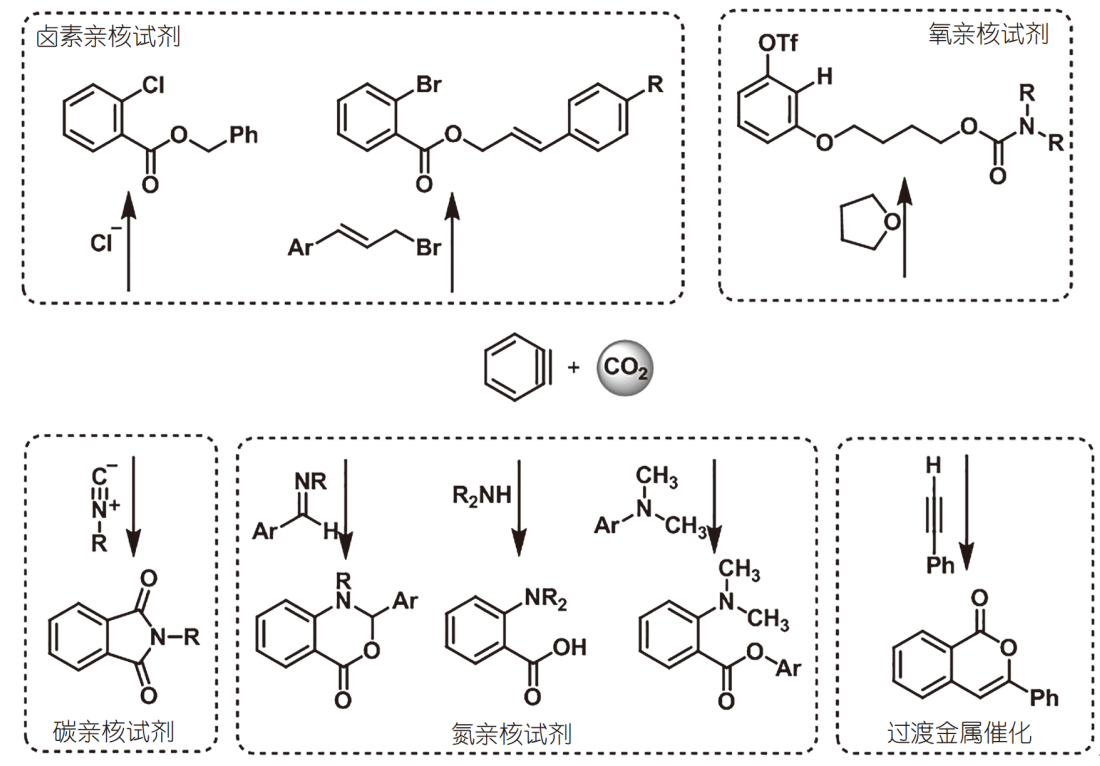

图 1 芳炔参与的二氧化碳化学转化反应

Figure $1 \quad \mathrm{CO}_{2}$ incorporation reaction with aryne 


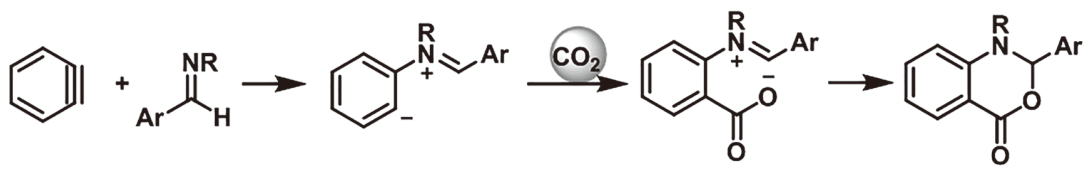

1

2

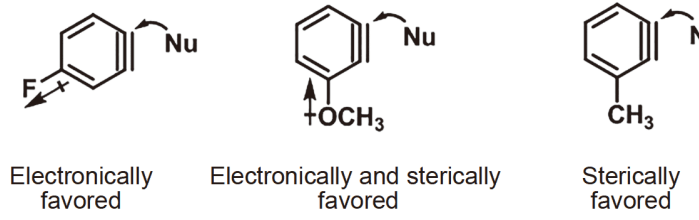

图 2 亚胺、芳炔、 $\mathrm{CO}_{2}$ 参与的三组分反应

Figure $2 \mathrm{CO}_{2}$ incorporation reaction using aryne and imine

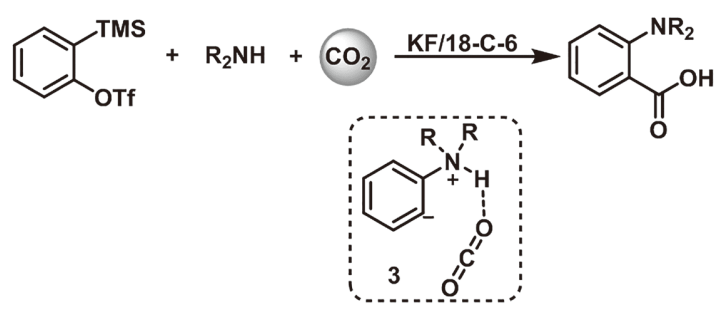

图 3 仲胺、苯炔、 $\mathrm{CO}_{2}$ 参与的三组分反应

Figure $3 \quad \mathrm{CO}_{2}$ incorporation reaction using aryne and secondary amine

发生在分子间，并且经过了铵盐的中间体6. 也就是说， 反应是由三级芳胺对苯炔的亲核进攻开始，产生的苯 基负离子被 $\mathrm{CO}_{2}$ 捕捉，得到两性离子中间体4. 当芳胺 的苯环上有给电子基团时，芳胺的烷基迁移到羧酸盐 的负离子上，得到烷基重排的产物 5 ; 苯环上的吸电子 基团会降低芳环的电子云密度，使其易于接受羧酸盐 氧负离子的亲核进攻，经由中间体6得到芳基迁移的产 物 7 .

\section{2 碳亲核试剂}

异氧基团的碳原子上同时有空轨道和孤对电子, 这就使得该碳原子同时表现出亲电性和亲核性. 因此 在参与多组分反应时，异腈可以作为亲核试剂发生加 成反应，同时可作为关环位点接受亲核试剂的进攻，这 一策略常被用于含氮杂环的合成 ${ }^{[21,22]}$. 2013年, 苏州大 学纪顺俊课题组 ${ }^{[23]}$ 报道了异腈、丁炔二酸二烷基酯、 $\mathrm{CO}_{2}$ 的环化反应，得到1,6-二氧杂螺 $[4,4]$ 壬烷-3,8-二烯 衍生物, 实现了基于 $\mathrm{CO}_{2}$ 结构中两个 $\mathrm{C}=\mathrm{O}$ 键的双氧杂环 的构建. 当使用苯炔替代丁炔二酸二烷基酯时, 异腈亲 核进攻苯炔产生芳基碳负离子 8 被 $\mathrm{CO}_{2}$ 捕获，而异腈还 可以接受中间体羧酸盐氧负离子 9 的亲核进攻，得到的 苯并二氢呋喃亚胺骨架10进一步接受体系中氟负离子 的亲核进攻，经由中间体11重排为取代的邻苯二甲酰 亚胺类化合物 ${ }^{[24,25]}$, 对照实验也证明了氟负离子诱导 的重排机理. 使用水替代 $\mathrm{CO}_{2}$ 时，则可以高收率地得到 苯甲酰胺类衍生物(图5)。氛代实验证明了该反应过程

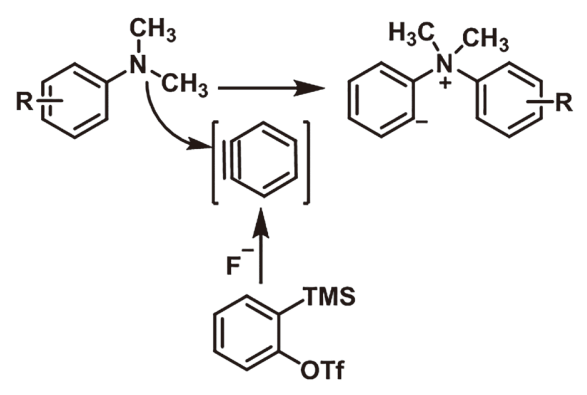

$\mathrm{CO}_{2}$<smiles>COC(=O)c1ccc(CCc2ccc(N(C)c3ccccc3C(C)=O)cc2)cc1N(C)c1ccc(F)cc1</smiles>

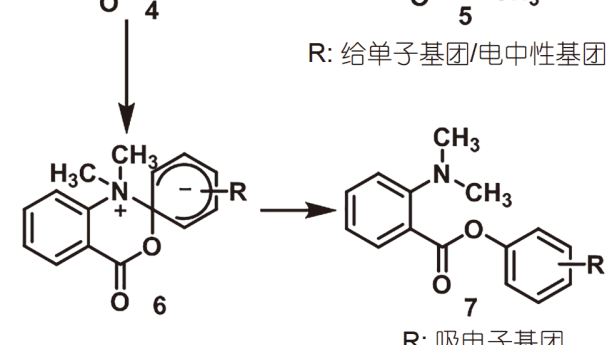

图 4 叔胺、苯炔、 $\mathrm{CO}_{2}$ 参与的三组分反应

Figure $4 \quad \mathrm{CO}_{2}$ incorporation reaction using aryne and tertiary amine 
首先是异腈对芳炔的亲核进攻，得到的芳基碳负离子 被水中的氢质子所捕获, 随后亚胺离子水解得到相应 的芳基酰胺衍生物.

\section{3 氧亲核试剂}

除了上述常见的亲核试剂外，含氧杂环也可以作 为亲核试剂诱发苯炔的多组分偶联反应 ${ }^{[26,27]}$. 2018年, 华南理工大学江焕峰课题组 ${ }^{[28]}$ 发展了室温常压下苯 炔、胺、含氧杂环以及 $\mathrm{CO}_{2}$ 的四组分偶联反应, 同时构 建了 $\mathrm{C}-\mathrm{O} 、 \mathrm{C}-\mathrm{N} 、 \mathrm{C}-\mathrm{H}$ 键, 得到氨基甲酸酯类衍生物. 一系列脂肪族伯胺、链状或环状仲胺都可以在温和条 件下发生偶联反应, 以较优的收率得到相应的偶联产 物. 值得注意的是, 只有基于 3-三氟甲磺基取代的芳炔 才可以发生此类反应，其原因可能是三氟甲磺基强吸 电子性质使得苯炔易于接受含氧杂环的亲核进攻. 而 三氟甲磺基还可以进一步发生衍生化，如与苯硼酸偶 联、水解为酚类化合物或者还原胺化等, 这就大大拓 展了该方法的使用范围. 结合已有的报道和对照实验, 作者提出可能的反应机理(图6)：反应进程中氧原子亲 核进攻芳炔产生的芳基负离子中间体 13被体系中原位 产生的氨基甲酸盐12的氢质子捕获, 得到中间体 14, 随 后氨基甲酸盐 12 的氧负离子亲核进攻中间体 14 的含氧
杂环, 得到氨基甲酸酯的产物.

\section{4 卤素亲核试剂}

芳香族卤化物是有机合成中重要的中间体，在有 机合成中起着桥梁的作用. 过渡金属催化的 $\mathrm{C}-\mathrm{C}$ 键的 形成反应大多需要芳基卤化物作为偶联试剂 ${ }^{[29,30]}$. 在 现代工业中, 碳-卤键还是杀虫剂、吸人式麻醉剂、除 草剂等的重要结构片段. 传统卤代芳烃的制备多是基 于芳环的亲电取代反应. 近年来, 芳炔插人卤代烃 $\mathrm{C}-\mathrm{X}$ 键的反应多有报道, 卤代烃主要是作为亲电试剂提供 相应的卤原子 ${ }^{[31,32]}$. 而在 2019 年, 华南理工大学江焕峰 课题组 ${ }^{[33]}$ 实现了苯炔、氯化钾、 $\mathrm{CO}_{2}$ 以及氯代烷烃的 四组分偶联反应, 同时构建了 $\mathrm{C}-\mathrm{Cl} 、 \mathrm{C}-\mathrm{C}$ 和 $\mathrm{C}-\mathrm{O}$ 键, 选择性地合成了医药和农药领域重要的中间体邻氯苯 甲酸酯类产物. 在此反应过程中, 氯化钾的氯离子作为 亲核试剂诱发苯炔与 $\mathrm{CO}_{2}$ 的偶联反应, 得到邻氯苯甲酸 负离子中间体 16, 随后中间体 16 与体系中作为溶剂的 二氯乙烷中的 $\mathrm{C}-\mathrm{Cl}$ 键发生亲核取代反应，构建了新的 $\mathrm{C}-\mathrm{O}$ 键; 而加人苄氯类衍生物, 则可以高收率合成邻氯 苯甲酸茮酯类衍生物 18 , 且芐氯苯环上的取代基对反 应活性没有影响(图7). 受此工作的启发, 印度科学研 究所Biju课题组 ${ }^{[34]}$ 发展了 KI、苯炔与醛的三组分偶联

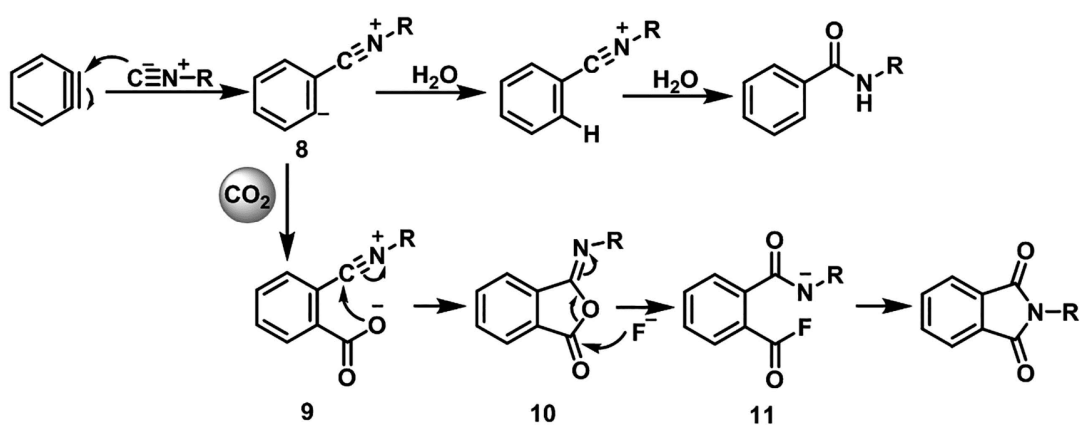

图 5 异腈、苯炔、 $\mathrm{CO}_{2}$ 参与的三组分反应

Figure $5 \quad \mathrm{CO}_{2}$ incorporation reaction using aryne and isonitrile

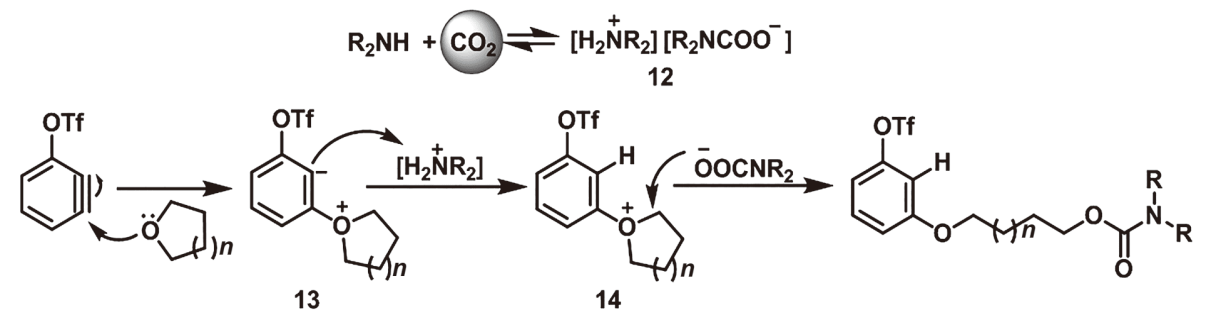

图 6 苯炔、胺、含氧杂环以及 $\mathrm{CO}_{2}$ 的四组分偶联反应

Figure 6 Synthesis of carbamate derivatives from $\mathrm{CO}_{2}$, arynes, amines and cyclic ethers 


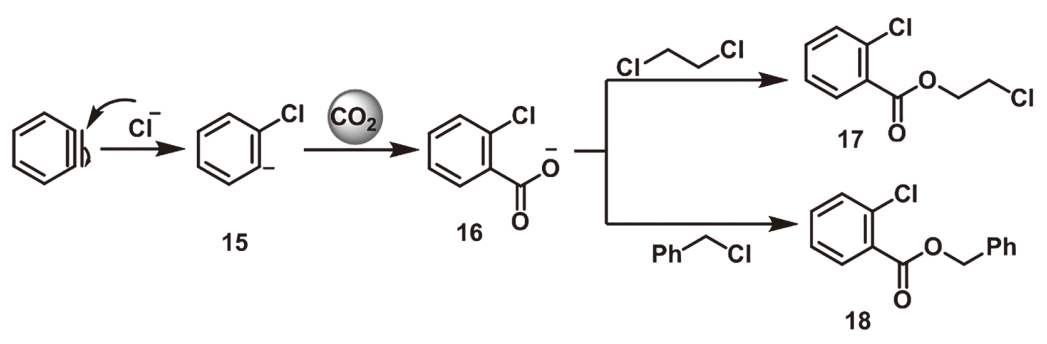

图 7 氯化钾、苯炔、二氯乙烷/苠氯与 $\mathrm{CO}_{2}$ 的四组分偶联反应

Figure 7 Synthesis of $o$-chloro benzoates from $\mathrm{CO}_{2}$, arynes, $\mathrm{KCl}$ and chloroalkanes

反应, 实现了2-碘代苯甲醇衍生物的高效合成.

除了无机卤化物的卤素负离子可以诱发苯炔参与 的多组分偶联反应，有机卤化物也被证明可以作为亲 核试剂启动苯炔的反应性，但是相关研究报道较少. 2007年，日本广岛大学的Yoshida课题组 ${ }^{[35]}$ 实现了苯甲 酰卤与芳炔的偶联反应. 来自苯甲酰卤的卤原子亲核 进攻苯炔产生芳基碳负离子，随后发生分子内的亲核 取代反应, 得到邻卤芳基酮类衍生物, 这为在芳环邻位 上引人酰基提供了新的思路. 来自肉桂基溴的溴原子 也被证明可以启动苯炔参与的偶联反应 ${ }^{[36]}$ ，诱发苯炔 产生芳基负离子 19 , 通入 $\mathrm{CO}_{2}$ 作为亲电试剂，即可实现 苯炔中间体的溴化羧基化反应，一步构建邻溴苯甲酸 烯丙酯类化合物 23 (图8). 肉桂基氯(活性太低)或者肉 桂基碘(活性太高)都被证明不能很好地发生此反应. 推 测的反应机理是: (1) 对于含有给电子基团的肉桂基溴, 其易于解离为稳定的烯丙基正离子和溴负离子，溴负 离子作为亲核试剂进攻苯炔, 产生的碳负离子被 $\mathrm{CO}_{2}$ 捕 获(中间体 20), 继而与烯丙基正离子成键，得到目标产 物;（2）对于含有吸电子基团的肉桂基溴，其对应的烯 丙基正离子不稳定，此时则是由肉桂基溴中的溴原子 亲核进攻苯炔(中间体 21)，进而发生后续的 $\mathrm{C}-\mathrm{C}$ 成键反 应(中间体22).

\section{2 过渡金属催化的反应}

炔基铜是有机合成中重要的活性中间体, $\mathrm{CO}_{2}$ 插人 $\mathrm{C}_{\mathrm{sp}}-\mathrm{Cu}$ 键构建炔酸类化合物已有报道 ${ }^{[37 \sim 39]}$ ，而炔基铜 试剂还可以与苯炔发生氧化加成，得到邻炔基芳基酮 试剂 ${ }^{[40,41]}$. 基于此，东京大学Kobayashi课题组 ${ }^{[42]}$ 实现 了芳炔、端炔以及 $\mathrm{CO}_{2}$ 在氮杂卡宾铜催化下的多组分 环化反应, 合成异香豆素类化合物(6-endo-dig型环化产 物). 苯乙炔芳环上的给电子取代基对反应没有影响, 吸 电子取代基会降低反应活性，而当乙炔基直接连在环 己烯、噻吩等 $\mathrm{sp}^{2}$ 杂化碳原子上时，也能以较好的收率

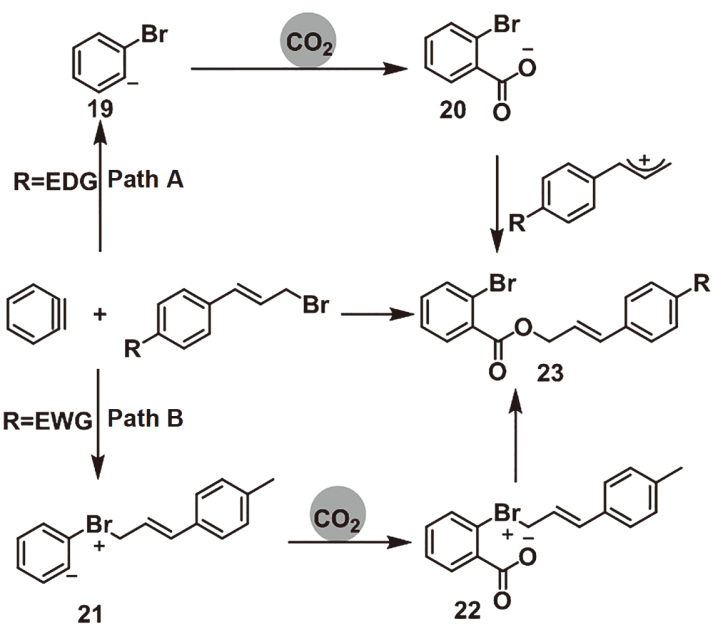

图 8 肉桂基溴、苯炔、 $\mathrm{CO}_{2}$ 的三组分偶联反应

Figure 8 Bromocarboxylation of arynes using allyl bromides and $\mathrm{CO}_{2}$

得到相应的产物．虽然已有报道卡宾铜可以催化端炔 与 $\mathrm{CO}_{2}$ 的羧化反应，但是由于芳炔的强亲电性，炔基铜 中间体 24首先与芳炔发生氧化加成，得到邻炔基芳基 铜中间体 25, 随后 $\mathrm{CO}_{2}$ 插人 $\mathrm{C}-\mathrm{Cu}$ 键(中间体 26), 关环得 到6-endo-dig的杂环产物27(图9). 这一研究思路拓展了 芳炔在 $\mathrm{CO}_{2}$ 多组分反应中的应用, 为制备更多的药物活 性中间体、天然产物等提供了参考。克级放大实验也 表明了该方法的实用价值.

\section{3 总结}

无论从环保还是资源利用的角度, $\mathrm{CO}_{2}$ 化学都是当 前绿色化学的研究热点. 将 $\mathrm{CO}_{2}$ 化学转化为高附加值的 化学产品极具潜力，尤其是从简单的原料出发，“一锅 法”构筑多个化学键，得到药物化学、农药学中常用的 杂环中间体. 苯炔是高活性的有机化学中间体, 在温和 条件下即可与富电子试剂作用，得到的苯基负离子中 间体继续与 $\mathrm{CO}_{2}$ 作用，生成稳定的结构，实现苯环邻位 同时构建两个官能团的策略, 因此苯炔参与的 $\mathrm{CO}_{2}$ 化学 


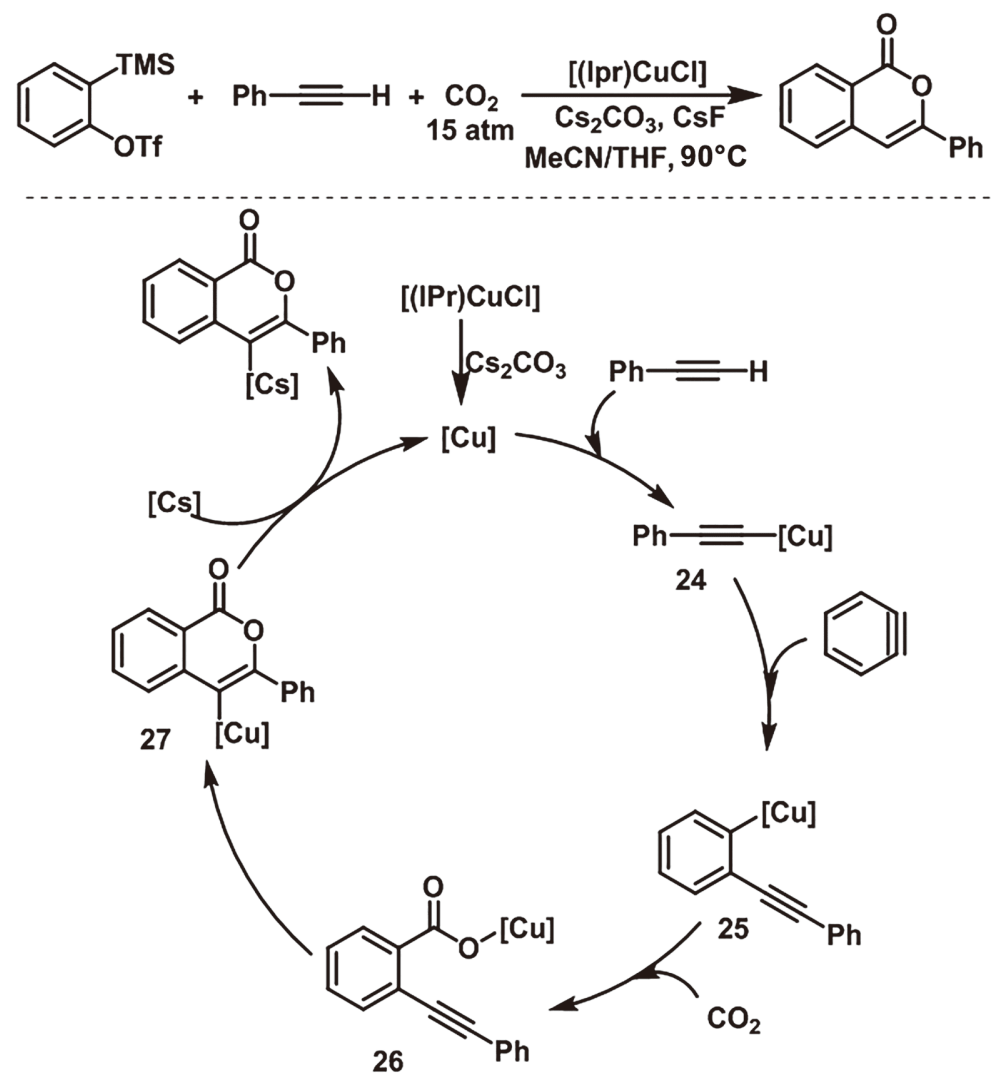

图 9 铜催化苯炔、苯乙炔、 $\mathrm{CO}_{2}$ 的三组分偶联反应

Figure 9 NHC-copper catalyzed three-component couplings of arynes, terminal Alkynes and $\mathrm{CO}_{2}$

转化反应具有重要的合成意义.

自1983年Kobayashi类苯炔前体被报道之后 ${ }^{[15]}$ ，苯 炔中间体快速地成为有机合成的研究热点. 然而苯炔 参与的 $\mathrm{CO}_{2}$ 化学转化反应的反应类型还不够丰富, 亲核 试剂类型比较单一, 过渡金属催化的反应报道较少. 这 可能是因为苯炔是高活性中间体，在反应过程中需要
兼顾其他试剂的反应性，这就增大了寻找匹配亲核试 剂和催化剂的难度. 因此, 苯炔化学与 $\mathrm{CO}_{2}$ 化学相结合, 具有很大的发展潜力和空间. 多组分串联反应、过渡 金属催化、光化学驱动等都有可能给该方向注人新的 活力. 可以预见随着研究的不断深人，基于苯炔固定 $\mathrm{CO}_{2}$ 的方法将会得到长足发展.

\section{参考文献}

1 He L N. Carbon Dioxide Chemistry (in Chinese). Beijing: Science Press, 2013 [何良年. 二氧化碳化学. 北京: 科学出版社, 2013]

2 He M Y, Sun Y H, Han B X. Development of green carbon science (in Chinese). Chin Sci Bull, 2015, 60: 1421-1423 [何鸣元, 孙予罕, 韩布兴. 绿 色碳科学发展. 科学通报, 2015, 60: 1421-1423]

3 Sakakura T, Choi J C, Yasuda H. Transformation of carbon dioxide. Chem Rev, 2007, 107: 2365-2387

4 Zhang W Z, Zhang N, Guo C X, et al. Recent progress in the cyclization reactions using carbon dioxide (in Chinese). Chin J Org Chem, 2017, 37: 1309-1321 [张文珍, 张宁, 郭春晓, 等. 二氧化碳参与的环化反应最新研究进展. 有机化学, 2017, 37: 1309-1321]

5 Song Q W, Zhou Z H, He L N. Efficient, selective and sustainable catalysis of carbon dioxide. Green Chem, 2017, 19: 3707-3728

6 Jing H W. Beyond chlorine reagents: Organic carbonate chemistry. In: Tundo P, He L, Lokteva E, et al., eds. Chemistry Beyond Chlorine. Switzerland: Springer International Publishing, 2016. 457-482

7 Yuan G Q, Qi C R, Wu W Q, et al. Recent advances in organic synthesis with $\mathrm{CO}_{2}$ as $\mathrm{C} 1$ synthon. Curr Opin Green Sustain Chem, 2017, 3: 22-27

8 Hong J T, Li M, Zhang J N, et al. C-H bond carboxylation with carbon dioxide. ChemSusChem, 2019, 12: 6-39 
9 Huang K, Sun C L, Shi Z J. Transition-metal-catalyzed C-C bond formation through the fixation of carbon dioxide. Chem Soc Rev, 2011, 40: 2435-2452

10 Tortajada A, Julió-Hernóndez F, Bçrjesson M, et al. Transition-metal-catalyzed carboxylation reactions with carbon dioxide. Angew Chem Int Ed, 2018, 57: 1594-15982

11 Manjolinho F, Arndt M, Gooßen K, et al. Catalytic C-H carboxylation of terminal alkynes with carbon dioxide. ACS Catal, 2012, 2: 2014-2021

12 Yeung C S, Dong V M. Beyond Aresta's complex: Ni- and Pd-catalyzed organozinc coupling with $\mathrm{CO}_{2}$. J Am Chem Soc, 2008, 130: 7826-7827

13 Ohishi T, Nishiura M, Hou Z. Carboxylation of organoboronic esters catalyzed by N-heterocyclic carbene copper(I) complexes. Angew Chem Int Ed, 2008, 47: 5792-5795

14 Shi M, Nicholas K M. Palladium-catalyzed carboxylation of allyl stannanes. J Am Chem Soc, 1997, 119: 5057-5058

15 Himeshima Y, Sonoda T, Kobayashi H. Fluoride-induced 1,2-elimination of $o$-(trimethylsilyl)phenyl triflate to benzyne under mild conditions. Chem Lett, 1983, 12: 1211-1214

16 Yoshida $\mathrm{H}$, Fukushima $\mathrm{H}$, Ohshita J, et al. $\mathrm{CO}_{2}$ incorporation reaction using arynes: Straightforward access to benzoxazinone. J Am Chem Soc, 2006, 128: 11040-11041

17 Liu Z, Larock R C. Facile N-arylation of amines and sulfonamides and O-arylation of phenols and arenecarboxylic acids. J Org Chem, 2006, 71: 3198-3209

18 Yoshida $\mathrm{H}$, Morishita T, Ohshita J. Direct access to anthranilic acid derivatives via $\mathrm{CO}_{2}$ incorporation reaction using arynes. Org Lett, 2008, 10: $3845-3847$

19 Liu Z, Larock R C. Facile N-arylation of amines and sulfonamides. Org Lett, 2003, 5: 4673-4675

20 Bhojgude S S, Roy T, Gonnade R G, et al. Substrate-controlled selectivity switch in the three-component coupling involving arynes, aromatic tertiary amines, and $\mathrm{CO}_{2}$. Org Lett, 2016, 18: 5424-5427

21 Kamijo S, Kanazawa C, Yamamoto Y. Copper- or phosphine-catalyzed reaction of alkynes with isocyanides. Regioselective synthesis of substituted pyrroles controlled by the catalyst. J Am Chem Soc, 2005, 127: 9260-9266

22 Oshita M, Yamashita K, Tobisu M, et al. Catalytic [4+1] cycloaddition of $\alpha, \beta$-unsaturated carbonyl compounds with isocyanides. J Am Chem Soc, 2005, 127: 761-766

23 Zhao L L, Wang S Y, Xu X P, et al. Dual 1,3-dipolar cycloaddition of carbon dioxide: Two $\mathrm{C}=\mathrm{O}$ bonds of $\mathrm{CO}_{2}$ react in one reaction. $\mathrm{Chem}$ Commun, 2013, 49: 2569-2571

24 Kaicharla T, Thangaraj M, Biju A T. Practical synthesis of phthalimides and benzamides by a multicomponent reaction involving arynes, isocyanides, and $\mathrm{CO}_{2} / \mathrm{H}_{2} \mathrm{O}$. Org Lett, 2014, 16: 1728-1731

25 Fang Y, Wang S Y, Ji S J. Synthesis of phthalimides through 1,3-dipolar cycloaddition of $\mathrm{CO}_{2}$ with isocyanides and arynes. Tetrahedron, 2015, 71: $2768-2771$

26 Yoshida H, Asatsu Y, Mimura Y, et al. Three-component coupling of arynes and organic bromides. Angew Chem Int Ed, 2011, 50: 9676-9679

27 Kentaro O, Yuta F, Akiko N, et al. Three component reaction of arynes with cyclic ethers and active methines: Synthesis of $\omega$-trichloroalkyl phenyl ethers. Bull Chem Soc Jpn, 2010, 83: 1238-1247

28 Xiong W F, Qi C R, Cheng R X, et al. A four-component coupling reaction of carbon dioxide, amines, cyclic ethers and 3-triflyloxybenzynes for the synthesis of functionalized carbamates. Chem Commun, 2018, 54: 5835-5838

$29 \mathrm{Fu} \mathrm{G} \mathrm{C.} \mathrm{The} \mathrm{development} \mathrm{of} \mathrm{versatile} \mathrm{methods} \mathrm{for} \mathrm{palladium-catalyzed} \mathrm{coupling} \mathrm{reactions} \mathrm{of} \mathrm{aryl} \mathrm{electrophiles} \mathrm{through} \mathrm{the} \mathrm{use} \mathrm{of} \mathrm{P}(\mathrm{t}-\mathrm{Bu})_{3}$ and $\mathrm{PCy}_{3}$ as ligands. Acc Chem Res, 2008, 41: 1555-1564

30 Fortman G C, Nolan S P. N-heterocyclic carbene (NHC) ligands and palladium in homogeneous cross-coupling catalysis: A perfect union. Chem Soc Rev, 2011, 40: 5151-5169

31 Li S J, Wang Y, Xu J K, et al. Formal insertion of imines (or nitrogen heteroarenes) and arynes into the C-Cl bond of carbon tetrachloride. Org Lett, 2018, 20: 4545-4548

32 Zhou M, Ni C, Zeng Y, et al. Trifluoromethyl benzoate: A versatile trifluoromethoxylation reagent. J Am Chem Soc, 2018, 140: 6801-6805

33 Jiang H F, Zhang Y, Xiong W F, et al. A three-phase four-component coupling reaction: Selective synthesis of $o$-chloro benzoates by $\mathrm{KCl}$, arynes, $\mathrm{CO}_{2}$, and chloroalkanes. Org Lett, 2019, 21: 345-349

34 Bhattacharjee S, Guin A, Gaykar R N, et al. Iodide as a nucleophilic trigger in aryne three-component coupling for the synthesis of 2-iodobenzyl alcohols. Org Lett, 2019, 21: 4383-4387

35 Yoshida H, Mimura Y, Ohshita J, et al. Insertion of arynes into carbon-halogen sigma-bonds: Regioselective acylation of aromatic rings. Chem Commun, 2007, 23: 2405-2407

36 Zhang Y, Xiong W F, Cen J H, et al. Direct bromocarboxylation of arynes using allyl bromides and carbon dioxide. Chem Commun, 2019, 55: 12304-12307

37 Li H R, He L N. Construction of C-Cu bond: A useful strategy in $\mathrm{CO}_{2}$ conversion. Organometallics, 2020, 39: 1461-1475 
38 Yu B, Xie J N, Zhong C L, et al. Copper(I)@carbon-catalyzed carboxylation of terminal alkynes with $\mathrm{CO}_{2}$ at atmospheric pressure. ACS Catal, 2015, 5: 3940-3944

39 Zhang W Z, Li W J, Zhang X, et al. Cu(I)-catalyzed carboxylative coupling of terminal alkynes, allylic chlorides, and $\mathrm{CO}_{2}$. Org Lett, 2010, 12: 4748-4751

40 Xie C, Liu L, Zhang Y, et al. Copper-catalyzed alkyne-aryne and alkyne-alkene-aryne coupling reactions. Org Lett, 2008, 10: $2393-2396$

41 Jeganmohan M, Bhuvaneswari S, Cheng C H. A cooperative copper- and palladium-catalyzed three-component coupling of benzynes, allylic epoxides, and terminal alkynes. Angew Chem Int Ed, 2009, 48: 391-394

42 Yoo W J, Nguyen T V, Kobayashi S. Synthesis of isocoumarins through three-component couplings of arynes, terminal alkynes, and carbon dioxide catalyzed by an NHC-copper complex. Angew Chem Int Ed, 2014, 53: 10213-10217 


\title{
Recent progress in $\mathrm{CO}_{2}$ transformation with arynes
}

\author{
Lan Liu \& Ran $\mathrm{Ma}^{*}$ \\ Shaanxi Key Laboratory of Chemical Additives for Industry, College of Chemistry and Chemical Engineering, Shaanxi University of Science \& \\ Technology, Xi'an 710021, China \\ * Corresponding author, E-mail: maran@sust.edu.cn
}

The concentration of $\mathrm{CO}_{2}$ in atmosphere has increased rapidly since the Industrial Revolution (by the time of May 2019, it has reached $414.7 \mathrm{ppm}$ ). Being one of the main greenhouse gases, $\mathrm{CO}_{2}$ has been widely blamed to be responsible for global warming. From the view point of chemistry, $\mathrm{CO}_{2}$ is also regarded as a sustainable and alternative carbon resource due to its nontoxic, low-cost and abundant. The use of $\mathrm{CO}_{2}$ as a $\mathrm{C} 1 \mathrm{raw}$ material instead of toxic phosgene or $\mathrm{CO}$ in organic synthesis has important ecological significance and economic value. However, only few industrial-scale chemical processes have been developed that use $\mathrm{CO}_{2}$ as a carbon source. The main reason for this is the chemical inertness associated with its thermodynamic and kinetic stability. In order to overcome such barriers, numerous useful synthetic methodologies by using highly active catalysts and reactant with a relatively high free energy have been developed for the incorporation of $\mathrm{CO}_{2}$ to organic compounds, such as carbonates, oxazolidinones, quinazolidine-2,4-diones.

Arynes, which have been widely used in various carbon-carbon and carbon-heteroatom bond synthesis, have highly strained $\mathrm{C} \equiv \mathrm{C}$ bonds and low lying lowest unoccupied molecular orbitals (LUMOs). Therefore, various nucleophiles such as amines, isocyanides, and imines can add to arynes, and the resultant zwitterions can be trapped by an electrophilic third component, thus leading to various three-component coupling reactions of high significance. When $\mathrm{CO}_{2}$ is used as the third component, thus constitutes a convenient method to install $\mathrm{CO}_{2}$ moiety directly to the aromatic ring, offering an excellent alternative access to aromatic carboxylic compounds. For example, Yoshida and co-workers reported the incorporation of $\mathrm{CO}_{2}$ in arynes multicomponent coupling triggered by imines and amines for the straightforward synthesis of benzoxazinones and anthranilic acid, respectively. Biju and co-workers disclosed the synthesis of phthalimides by a nulticomponent reaction involving arynes, isocyanides and $\mathrm{CO}_{2}$. Other nucleophiles, such as ethers, allyl bromides, aromatic tertiary amines and $\mathrm{KCl}$, have also been demonstrated to trigger the multicomponent coupling reactions involving benzynes and $\mathrm{CO}_{2}$. Therefore, this minireview highlights recent advances on the $\mathrm{CO}_{2}$ incorporation reactions with arynes induced by various nucleophilic reagents or catalyzed by transition metal. Reaction characteristics and mechanisms will be discussed in detail. Accordingly, the rational design of nucleophiles and development of efficient catalysts are crucial for incorporation of $\mathrm{CO}_{2}$ into arynes, realizing the simultaneously establishing two functional groups at the ortho position of the benzene ring. The significant progress in this field will stimulate further interest in research for heterocycle construction using $\mathrm{CO}_{2}$ as a carboxylating reagent and will open new avenues in the total synthesis of complex natural products. It will be interesting to witness future advances in this topical field.

arynes, nucleophiles, $\mathrm{CO}_{2}$ transformation, multicomponent reaction, aromatic carboxylic compounds

doi: 10.1360/TB-2020-0353 